\title{
Human blood platelets and viruses: defense mechanism and role in the removal of viral pathogens
}

\author{
Masresha Seyoum ${ }^{1,2}$, Bamlaku Enawgaw $^{2^{*}}$ (D) and Mulugeta Melku²
}

\begin{abstract}
Platelets are small non-nucleated cell fragments and the second most abundant cell that play crucial role in managing vascular integrity and regulating hemostasis. Recent finding shows, beyond its hemostatic function platelets also play a main role in fighting against pathogen including viruses. With their receptors, platelet interacts with viral pathogen and this interaction between platelets and viral pathogens result in activation of platelets. Activated platelet releases different molecules that have antiviral activity including kinocidins and other platelet microbicidal peptides. In addition, activated platelet has antiviral role by different mechanism including; phagocytosis of viral pathogen, produce reactive oxygen species and interact with and activate other immune cells. In other side, antiplatelet treatments are one of defending mechanism of viral pathogen. This narrative review summarizes what is known regarding the role of human platelets in fighting viral pathogen.
\end{abstract}

Keywords: Platelets, Viral infections, Platelet activations, Platlet granules, Viral defense mechanisms

\section{Background}

Platelets are small discoid shaped non-nucleated cells with 1-3 $\mu \mathrm{m}$ size in diameter. They originated from bone marrow megakaryocytes (MKs) cytoplasm and circulate in the vascular system to play a main role in haemostasis and thrombosis. In normal healthy individual, platelets are the second most abundant cells next to red blood cells (RBCs) with $150,000-450,000$ cells $/ \mu \mathrm{L}[1-3]$. These number account about $70 \%$ of the platelets in the peripheral blood. The remaining $30 \%$ body platelets are stored in the spleen [3].

Platelets have a main function in hemostasis and blood coagulation. They involve in the prevention of bleeding disorders, mainly in the primary hemostasis. Following vascular injury, sub endothelial collagen is exposed. Then plasma von Willebrand factor (vWF), which is secreted by platelets and endothelial cells, anchor onto the collagen. Platelet vWF receptor (glycoprotein Ib $\alpha$ ) interacts with vWF and initiates platelets to the injured site

\footnotetext{
*Correspondence: bamlak21@gmail.com

${ }^{2}$ Department of Hematology \& Immunohematology, School of Biomedical and Laboratory Sciences, College of Medicine and Health Sciences, University of Gondar, Gondar, Ethiopia

Full list of author information is available at the end of the article
}

[4]. Then they became activated and release different molecules such as von Willebrand factor (vWF), thromboxane A2, phospholipids, ADP and others [5]. ADP involved in attraction of more platelets to the injured area and thromboxane $A_{2}$ promotes platelet aggregation to form platelet plug. This platelet plug minimizes bleeding and promote blood coagulation process [4].

Now a day, different evidence showed that platelets have an ability to interact with and internalize pathogens including viruses [6-9], beyond their main function in hemostasis and blood coagulation [4,5]. These functions are achieved through direct interaction with leukocytes, endothelial cells and via release of soluble inflammatory mediators that enhance recruitment and activation of leukocytes [6, 10-14].

In addition to binding function, platelets also involve in phagocytosis by enhancing antigen presentation by antigen presenting cells [15-18]. But their role in viral infection response is not fully understood. Their interaction to viruses may have benefit or risk for the host. Therefore, this narrative review aimed to summarize the current knowledge on the role of blood platelets in fighting viral pathogens. This review focused on new and 
emerging concepts related to defending role and mechanism of platelets against viral infections.

\section{Mechanism of human platelets in defending viral pathogen}

On their surface platelets have receptors for viral pathogens that facilitate the direct interaction of platelets with viral pathogens. This interaction between platelets and viral pathogens through different receptors cause quantitative (thrombocytopenia) and qualitative platelets dysfunction associated with viral pathogen [6, 19-23]. Beside this, the recent findings indicate that platelets play a main role in defending viral pathogen and has adverse effect against viral infection. It shows that binding of viral pathogen with platelets not only result in clearance of platelets but also clearance of viral pathogens caused by platelets $[6,7]$.

\section{Platelet receptors to recognize viral pathogens}

Different receptors that found on the surface of platelets enable platelets to sense the presence of viral pathogens [24]. Platelets and megakaryocytes express messenger ribonucleic acid (mRNA) and/or protein for the toll like receptors (TLR 1, TLR 2, TLR3, TLR 4, TLR 6, TLR 7, TLR 8 and TLR 9) that detect and bind viral components at the cell surface and viral nucleic acids [9, 25-32]. These TLRs are important for binding of platelets to pathogens such as bacteria, parasites and protozoa and important for their clearance [8, 9, 13, 30, 33].

Also, platelets express several complement receptors, including CR2, CR3, CR4, C3aR, C5aR, gC1qR and cClqR [34]. These complements act as receptor for pathogens and implements multiple functions in direct and indirect antimicrobial host defense, including, cell lysis, opsonization and chemotaxis [35]. Megakaryocytes express CD4 [36] while both MKs and platelets express CXCR1, 2, 4 and CCR3 co receptors used for interaction with HIV-1 [17, 37].

Additionally, platelet granules express Dendritic CellSpecific ICAM3-Grabbing Non-integrin (DC-SIGN) [18, $38]$ and C-type lectin receptor 2 (CLEC-2) $([18,39])$ which are used for the interaction with HIV-1 $[18,38]$ Platelet surface receptors such as DC-SIGN or enhancement of the receptor FcyII play important role in binding of platelets with Dengue virus (DENV). DC-SIGN and heparin sulphate proteoglycan are receptors for DENV and the combination of anti-DC-SIGN and lowmolecular-wType equation here.eight heparin prevent binding of platelets with DENV $[19,22]$. DENV infection leads to thrombocytopenia by increasing phagocytosis of DV-induced apoptosis platelets by macrophages via a Phosphatidylserine-recognizing pathway $[23,40]$.

Among the receptors, alpha $v$ beta $3(\alpha v \beta 3)$ or alpha $v$ beta $5(\alpha v \beta 5)$ interact with adenoviruses [41] and platelet glycol proteins GPIa/IIa ( $\alpha 2 \beta 1$ integrin) and GPVI (a member of the Ig super family and primary signalling receptor for platelet activation by collagen) bind viruses [42]. Platelets also express Coxsackie-Adeno receptor (CAR). This receptor is important for the interaction of Coxsackieviruses B (CVB) with platelets. Although CVB virus does not replicate in platelets, it triggers P-selectin and Phosphatidylserine (PS) membrane expression. Expression of P-selectin and PS as the main mediators of platelet with leukocyte interactions and promoting their phagocytosis by macrophages [43].

Although, platelets do not express $\mathrm{HCV}$ receptors such as CD81 [44]; they express glycoprotein VI (GPVI) which is a receptor used to form interaction between HCV and platelets [45]. Studies demonstrated that individuals with HPA-1a/1b, HPA-2b and HPA-5b alleles had a higher risk for HCV than those individuals with HPA-2a and HPA -5b alleles [46-48]. Table 1 summarizes different viruses and their receptors on the platelets.

\section{Pro-inflammatory activity of platelets}

After platelets bind and phagocytes infectious microorganism, they become activated and undergo degranulation and release a variety of inflammatory mediators, chemokines and cytokines from their granules. Adenosine diphosphate (ADP), thromboxane A2 (TXA2),

Table 1 Platelet receptors for viruses

\begin{tabular}{|c|c|c|}
\hline Receptor & Viruses & Reference \\
\hline \multirow[t]{5}{*}{$a_{v} \beta_{3}$} & Hantaviruses & {$[6,73,74]$} \\
\hline & Coxsackievirus A9, A16, & \\
\hline & Human adenovirus type 2 & \\
\hline & Echovirus 9 & \\
\hline & Human parechovirus & \\
\hline$a_{\| 1} \beta_{3}$ & Hantaviruses & {$[6,73,74]$} \\
\hline \multirow[t]{2}{*}{$a_{2} \beta_{1}$} & Echovirus 1 & {$[75,76]$} \\
\hline & Rotavirus & \\
\hline DC-SIGN & Lentiviruse, HIV & {$[9,38]$} \\
\hline DC-SIGN & Ebola virus & {$[77,78]$} \\
\hline$A \times l$ & Lassa fever virus (LASV) & \\
\hline \multicolumn{3}{|l|}{ Tyro3 } \\
\hline $\begin{array}{l}\text { CCR-3 \& 4, CXCR-1, } 2 \text { \& 4, } \\
\text { CLEC-2, DC-SIGN }\end{array}$ & HIV & {$[7,18]$} \\
\hline GP-VI & $\mathrm{HCV}$ & {$[7,9]$} \\
\hline CR2 & EBV & {$[6,7,79]$} \\
\hline$a_{2} \beta_{1}$ & Rotavirus & {$[7,9]$} \\
\hline$a_{2 b} \beta_{3}\left(G P_{\|b\| l \mid a}\right)$ & Adenovirus & {$[6,7]$} \\
\hline
\end{tabular}

N.B: CLEC-2: C-type lectin-like type II transmembrane receptor; CR-2: Complement Receptor type 2; CCR-1, CCR-3, CCR-4: C-C Chemokine Receptor type 1, 3 and 4; CXCR-1, CXCR-2, CXCR-4: C-X-C chemokine receptor type 1,2 and 4. DC-SIGN: Dendritic Cell-Specific Intercellular adhesion molecule-3-Grabbing Non-integrin; GP-VI: Glycoprotein VI; PAR-1/PAR-4: Platelet Activating Receptor $1 / 4$ 
serotonin, cytokines (IL-1 $\beta, \mathrm{TNF} \alpha, \mathrm{TGF}-\beta, \mathrm{CD} 40 \mathrm{~L})$ and chemokines (CXCL1 (GROa), CXCL4/PF4, CXCL5, CXCL7, CXCL12, CXCL14, CCL5 (RANTES), CCL3 (MIP1a), MCP-3 (CCL7)) are released. These plateletderived chemokines and cytokines stimulate migration of monocytes and enhances phagocytosis [13, 14, 49-51].

Platelet dense $(\delta)$ granules contain nucleotides (ADP and GTP); bioactive amines (histamine and serotonin); and bioactive ions ( $\mathrm{Ca} 2+$ and $\mathrm{PO} 3-)$ while alpha $(\alpha)$ granules contain adhesion molecules; platelet microbicidal proteins (PMPs) and kinocidins. The releasing of $\alpha$ - granules provide platelet-mediated host defense mechanisms, as they contain kinocidins and microbicidal proteins which is important for antiviral host defense [50].

Also, when there was infection, platelets play a main role in defending pathogens by activating immune cells. They send signals to immune cells by releasing chemokines that attract and recruit immune cells to the site of infection [52, 53]. For this function, kinocidins, in addition to its antimicrobial activity, play the main role in attraction and activation of phagocytes and lymphocytes [54].

The cleaving of kinocidins and antimicrobial peptides by thrombin and pathogens; give broad and strong antimicrobial property for platelets. For example, the common kinocidins, platelet factor 4 (PF-4) which is a small cytokine belonging to the CXC family, CXCL4, are inhibitor of HIV-1 and suppresses HIV-1 infection of T-lymphocytes. [55-57]. Similar to granulocytes, platelet have direct antimicrobial functions that are mediated by secretion of antimicrobial molecules such as platelet microbicidal peptides (PMPs). PMPs are stored in platelet granules and can kill microorganisms including viruses, when they released during platelet activation and degranulation [58]. Forexample, platelets show a direct interaction with HIV-1 through different mechanisms such as binding, engulfment, and internalization, all of which play a role in host defense during HIV-1 infection, by limiting viral spread and probably by inactivating viral particles [59].

Different observation gives evidence for antiviral activity of antimicrobial peptides. Nine synthetic antimicrobial peptides, four originating from thrombininduced human platelet-derived antimicrobial proteins named PD1-PD4 and five synthetic repeats of arginine-tryptophan repeats (RW1-5) demonstrate for their antiviral activity for vaccinia virus (VV) [60].

Up on activation platelets also release defensin $(\alpha$ and $\beta$ ) which have anti-viral role. For example, human alphadefensins 1-3 and human alpha-defensin 5 are potent antagonists of papilloma virus types and human betadefensins 1 and 2 displayed little anti- human papilloma virus activity [61].

\section{Platelet ROS production}

Reactive Oxygen Species (ROS) are diffusible and shortlived molecules that have a major role in platelet activation regulation. In turn, different observations clearly indicate that, activated platelets have the capability to synthesize ROS such as $\mathrm{H}_{2} \mathrm{O}_{2},-\mathrm{OH}$ and peroxynitrite $\left(\mathrm{NO}_{3}^{-}\right)$, which are able to modify platelet function [62, 63]. The released ROS from platelets has antimicrobial role and contribute in defending role of platelets by killing of pathogens [64]. It is widely accepted that the ROS produced by phagocytes during respiratory burst contribute to the elimination of pathogens. For example, recent experiments demonstrated that ROS inhibit human cytomegalovirus (HCMV) infection [65].

\section{Platelet phagocyte function}

Accumulating evidence suggests that, during direct interaction of viral pathogens with human platelets, there is a phagocytosis of viral pathogens by platelets and so enables their transport for a prolonged time. During viral infections there will be expression of P-selectin and PS, which increases platelet-leukocyte interactions and promoting phagocytosis of platelets and viruses by macrophages [23, 43].

HIV is best example to show phagocytosis activity of platelets and conducted research showing that, in platelets incubated with HIV; HIV antigen was found in engulfing vacuoles and the open canalicular system (OCS) and also Immunogold labelling for the viral core protein p24 confirmed the presence of HIV within platelets, which is also true in vivo [66].

Another finding also support phagocytosis role of platelets and platelet suspension incubated with influenza virus were observed by electron microscope, and finding shows that platelets found with virus containing vacuoles, which suggesting that the platelets had rapidly phagocytosed the viruses. Phagocytosis of influenza virus by platelets may play an important role in the occurrence of thrombocytopenia during influenza infection and may also a mechanism of virus clearance during infection [67]. Similar finding is observed in the role of platelets in the clearance of respiratory syncytial virus (RSV) by internalizing viral particles and by enhancing type I IFN production from peripheral blood mononuclear cells [68].

\section{Platelets interaction with other immune cells}

In addition of direct interaction with pathogens and secretion of antimicrobial agents, platelets also interact with other immune cells. After activation platelets secrete a number of chemokines attracting neutrophils as well as cytokines CD40L and IL-1 $\beta$ which inflame endothelial cells. Inflamed endothelial cells express an 
array of adhesion molecules, such as ICAM-1, VCAM$1, \mathrm{P}$ and E-selectin, promoting neutrophils recruitment [52]. P-Selectin interacts with P -selectin glycoprotein ligand-1 (PSGL-1) and expressed on the surface of leukocytes. This interaction cause, leukocyte mediated immune responses during viral infections by phagocytosis and enhanced reactive oxygen production of neutrophils [69].

Interaction of CD40L on T cells with CD40 on B cells is of paramount importance for the development and function of the humoral immune system. Recent report also indicates that platelets express CD40L when they are activated and interact with CD40 of leukocytes and increases reactive oxygen species (ROS) production by neutrophils which enhance their capacity to phagocytose pathogens $[17,52]$.

Human cytomegalovirus (HCMV) bind to platelet receptor, TLR 2, that are found on platelet which causes activation and degranulation of HCMV-activated platelet and cause platelets binding to and activate neutrophils results in neutrophils mediated immune response [17]. Also in patients infected with dengue virus, there is direct interaction between platelets and antigen which activate platelets. These activated platelets bind with monocytes and help to enhance immune response for pathogen [70].

Platelets have antigen presenting role [17]. Demonstrated evidences shows that, platelets express $\mathrm{T}$ cell costimulatory molecules; process and present antigen in MHC class $\mathrm{I}$, and directly activate naive $\mathrm{T}$ cells in a platelet MHC class I-dependent manner. Platelets present pathogen derived antigen to promote $\mathrm{T}$ cell responses in vivo; which proofs the novel antigen presentation role of platelets [71]. In a murine model of lymphocytic choriomeningitis virus (LCMV) infection, platelets prevented lethal hemorrhagic anemia by promoting cytotoxic $\mathrm{T}$ lymphocyte (CTL) dependent clearance of the virus [72].

\section{Conclusion}

Beyond their primary role in hemostasis, platelets also play a main role in defending viral pathogens. Much more experimental studies give evidence for the antiviral role of platelet and clearly show the binding capacity of platelets with different viral pathogens with their receptors. Platelets activated and initiate their antimicrobial host defense by sensing the presence of pathogens or inflammation through immune receptors such as immunoglobulin or complement receptors and TLRs. After activation platelets secrete a number of chemokines that attract other immune cells which is contribute for the clearance of viruses. Platelet has direct antimicrobial functions that are mediated by secretion of antimicrobial molecules including platelet microbicidal peptides and kinocidins. This antimicrobial peptides releases during platelets activation and kill viral pathogens. The other antiviral role of platelets is killing of viruses by phagocytosis. It is widely accepted that the ROS produced by phagocytes during respiratory burst contribute to the elimination of pathogens. Platelets also produce ROS upon activation which inhibit viruses.

\section{Abbreviations \\ ADP: Adenosine diphosphate; ATP: Adenosine triphosphate; C1q: First complement component; CD: Cluster of differentiation; CD40L: CD40 Ligand; CLEC-2: C-type lectin receptor 2; CXCL4: Chemokine (C-X-C motif) ligand 4, or platelet factor 4 (PF4); DC-SIGN: Dendritic cell-specific ICAM-grabbing non- integrin; DENV: Dengue virus; FcyRlla: IgG Fcylla region receptor; HCMV: Human cytomegalovirus; HCV: Hepatitis C virus; HIV: Human immunodeficiency virus; Ig: Immunoglobulin; IL: Interleukin; PAR: Protease- activated receptor; PF4: Platelet factor 4; PMPs: Platelet microbicidal proteins; ROS: Reactive oxygen species; TLR: Toll-like receptor; TNF: Tumour necrosis factor; vWF: von Willebrand factor}

Availability of data and materials

Data sharing not applicable to this article as no datasets were generated or analysed during the current study.

\section{Authors' contributions}

MS \& BE performed literature searching and drafted the manuscript. MM involved in drafting of the manuscript along with MS \& BE. All authors read and approved the final manuscript.

Ethics approval and consent to participate Not applicable.

\section{Competing interests}

The authors declare that they have no competing interests.

\section{Publisher's Note}

Springer Nature remains neutral with regard to jurisdictional claims in published maps and institutional affiliations.

\section{Author details}

${ }^{1}$ University of Gondar hospital, College of Medicine and Health Sciences, University of Gondar, Gondar, Ethiopia. ${ }^{2}$ Department of Hematology \& Immunohematology, School of Biomedical and Laboratory Sciences, College of Medicine and Health Sciences, University of Gondar, Gondar, Ethiopia.

Received: 4 December 2017 Accepted: 18 April 2018

Published online: 17 July 2018

\section{References}

1. Italiano J, Hartwig JH, Michelson A. Megakaryocyte development and platelet formation. Platelets. 2007;2:23-44.

2. George J. Overview of platelet structure and function. In: Colman RW, Hirsh J, Marder VJ, Clowes AW, George JN, editors. Hemostasis and thrombosis: basic principles and clinical practice. Philadelphia: Lippincott, Williams and Wilkins; 2001. p. 381-6.

3. Keohane EM, Smith LJ, Walenga JM. Rodak's hematology: clinical principles and applications. 5th ed. Rivrport lane St. Louis, Missouri: Elsevier Health Sciences; 2016.

4. Hou Y, Carrim N, Wang Y, Gallant RC, Marshall A, Ni H. Platelets in hemostasis and thrombosis: novel mechanisms of fibrinogen-independent platelet aggregation and fibronectin-mediated protein wave of hemostasis. Journal of biomedical research. 2015;29(6):437

5. Rendu F, Brohard-Bohn B. The platelet release reaction: granules' constituents, secretion and functions. Platelets. 2001;12(5):261-73.

6. Assinger A. Platelets and infection - an emerging role of platelets in viral infection. Front Immunol. 2014;5:649. 
7. Chabert A, Hamzeh-Cognasse H, Pozzetto B, Cognasse F, Schattner M, Gomez RM, et al. Human platelets and their capacity of binding viruses: meaning and challenges? BMC Immunol. 2015;16:26.

8. Kapur R, Semple JW. Platelets as immune-sensing cells. Blood advances Blood Adv. 2016;1(1):10-4.

9. Cognasse F, Nguyen KA, Damien P, McNicol A, Pozzetto B, HamzehCognasse $\mathrm{H}$, et al. The inflammatory role of platelets via their TLRs and Siglec receptors. Front Immunol. 2015;6:83.

10. Weyrich A, Lindemann S, Zimmerman $\mathrm{G}$. The evolving role of platelets in inflammation. J Thromb Haemost. 2003;1(9):1897-905.

11. Engelmann B, Massberg S. Thrombosis as an intravascular effector of innate immunity. Nat Rev Immunol. 2013;13(1):34-45.

12. Semple JW, Freedman J. Platelets and innate immunity. Cell Mol Life Sci. 2010;67(4):499-511.

13. Morrell CN, Aggrey AA, Chapman LM, Modjeski KL. Emerging roles for platelets as immune and inflammatory cells. Blood. 2014;123(18):2759-67.

14. Jenne C, Urrutia R, Kubes P. Platelets: bridging hemostasis, inflammation, and immunity. Int J Lab Hematol. 2013;35(3):254-61.

15. Nagasawa T, Nakayasu C, Rieger AM, Barreda DR, Somamoto T, Nakao M. Phagocytosis by thrombocytes is a conserved innate immune mechanism in lower vertebrates. Front Immunol. 2014;5:445.

16. Meseguer J, Esteban MA, Rodriguez A. Are thrombocytes and platelets true phagocytes? Microsc Res Tech. 2002;57(6):491-7.

17. Ali RA, Wuescher LM, Worth RG. Platelets: essential components of the immune system. Current trends in immunology. 2015;16:65-78.

18. Chaipan C, Soilleux EJ, Simpson P, Hofmann H, Gramberg T, Marzi A, et al. DC-SIGN and CLEC-2 mediate human immunodeficiency virus type 1 capture by platelets. J Virol 2006;80(18):8951-8960. Epub 2006/08/31.

19. Simon AY, Sutherland MR, Pryzdial EL. Dengue virus binding and replication by platelets. Blood. 2015;126(3):378-85.

20. Parikh F. Infections and thrombocytopenia. J Assoc Physicians India. 2016; 64(2):11-2.

21. Wang CS, Yao WJ, Wang ST, Chang TT, Chou P. Strong association of hepatitis $\mathrm{C}$ virus ( $\mathrm{HCV}$ ) infection and thrombocytopenia: implications from a survey of a community with hyperendemic HCV infection. Clinical infectious diseases : an official publication of the Infectious Diseases Society of America. 2004;39(6):790-6.

22. Hottz ED, Oliveira MF, Nunes PC, Nogueira RMR, Valls-de-Souza R, Da Poian AT, et al. Dengue induces platelet activation, mitochondrial dysfunction and cell death through mechanisms that involve DC-SIGN and caspases. Thromb Haemost. 2013;11(5):951-62.

23. Alonzo MT, Lacuesta TL, Dimaano EM, Kurosu T, Suarez LA, Mapua CA, et al. Platelet apoptosis and apoptotic platelet clearance by macrophages in secondary dengue virus infections. J Infect Dis. 2012;205(8):1321-9.

24. Hunelshausen $P$, Weber C. Platelets as immune cells. Bridging inflammation and cardiovascular disease. The review is part of a thematic series on mechanisms, models, and in vivo imaging of thrombus formation. Circ Res. 2007;100:27-40.

25. Andonegui $G$, Kerfoot SM, McNagny K, Ebbert KV, Patel KD, Kubes $P$. Platelets express functional toll-like receptor-4. Blood. 2005;106(7):2417-23.

26. D'atri LP, Etulain J, Rivadeneyra L, Lapponi MJ, Fondevila C, Schattner M. Expression and functionality of toll-like receptor 3 in the megakaryocytic lineage. J Thromb Haemost. 2013;11:514-5.

27. Koupenova M, Vitseva O, MacKay CR, Beaulieu LM, Benjamin EJ, Mick E, et al. Platelet-TLR7 mediates host survival and platelet count during viral infection in the absence of platelet-dependent thrombosis. Blood. 2014;124(5):791-802.

28. Shiraki R, Inoue N, Kawasaki S, Takei A, Kadotani M, Ohnishi Y, et al. Expression of toll-like receptors on human platelets. Thromb Res. 2004; 113(6):379-85

29. Thon JN, Peters CG, Machlus KR, Aslam R, Rowley J, Macleod H, et al. T granules in human platelets function in TLR9 organization and signaling. J Cell Biol. 2012;198(4):561-74

30. Garraud O, Cognasse F. Platelet toll-like receptor expression: the link between "danger" ligands and inflammation. Inflammation \& Allergy-Drug Targets (Formerly Current Drug Targets-Inflammation \& Allergy). 2010;9(5):322-33.

31. Aslam R, Speck ER, Kim M, Crow AR, Bang KW, Nestel FP, et al. Platelet tolllike receptor expression modulates lipopolysaccharide-induced thrombocytopenia and tumor necrosis factor-alpha production in vivo. Blood. 2006;107(2):637-41.

32. Panigrahi $S$, Ma $Y$, Hong L, Gao D, West $X Z$, Salomon RG, et al. Engagement of platelet toll-like receptor 9 by novel endogenous ligands promotes platelet hyper-reactivity and thrombosis. Circ Res. 2012;112(1):103-12. CIRCRESAHA. 112.274241

33. $D^{\prime}$ Atri LP, Schattner M. Platelet toll-like receptors in thromboinflammation. Frontiers in bioscience (Landmark edition). 2017:22:1867-83.

34. Martel C, Cointe S, Maurice P, Matar S, Ghitescu M, Théroux P, et al. Requirements for membrane attack complex formation and anaphylatoxins binding to collagen-activated platelets. PLoS One. 2011;6(4):e18812.

35. Rambach G, Würzner R, Speth C. Complement: an efficient sword of innate immunity. Trends in Innate Immunity. Basel: Karger Publishers; 2008. p. 78-100.

36. Basch RS, Dolzhanskiy A, Zhang XM, Karpatkin S. The development of human megakaryocytes. II. CD4 expression occurs during haemopoietic differentiation and is an early step in megakaryocyte maturation. $\mathrm{Br} J$ Haematol. 1996;94(3):433-42.

37. Riviere C, Subra F, Cohen-Solal K, Cordette-Lagarde V, Letestu R, Auclair C, et al. Phenotypic and functional evidence for the expression of CXCR4 receptor during Megakaryocytopoiesis. Blood. 1999;93(5):1511-23.

38. Boukour S, Masse JM, Benit L, Dubart-Kupperschitt A, Cramer E. Lentivirus degradation and DC-SIGN expression by human platelets and megakaryocytes. J Thromb Haemost. 2006;4(2):426-35.

39. Gitz E, Pollitt AY, Gitz-Francois JJ, Alshehri O, Mori J, Montague S, et al. CLEC-2 expression is maintained on activated platelets and on platelet microparticles. Blood. 2014;124(14):2262-70.

40. Kar M, Singla M, Chandele A, Kabra SK, Lodha R, Medigeshi GR. Dengue virus entry and replication does not lead to productive infection in platelets. Open forum infectious diseases. 2017;4(2):ofx051.

41. Eggerman TL, Mondoro TH, Lozier JN, Vostal JG. Adenoviral vectors do not induce, inhibit, or potentiate human platelet aggregation. Hum Gene Ther. 2002;13(1):125-8.

42. Flaujac C, Boukour S, Cramer-Bordé E. Platelets and viruses: an ambivalent relationship. Cell Mol Life Sci. 2010;67(4):545-56.

43. Negrotto $S$, Jaquenod de Giusti $C$, Rivadeneyra $L$, Ure AE, Mena HA, Schattner $M$, et al. Platelets interact with Coxsackieviruses B and have a critical role in the pathogenesis of virus-induced myocarditis. Journal of thrombosis and haemostasis : JTH. 2015;13(2):271-82.

44. Padovani JL, Corvino SM, Drexler JF, Silva GF, Pardini MI, Grotto RM. In vitro detection of hepatitis $C$ virus in platelets from uninfected individuals exposed to the virus. Rev Soc Bras Med Trop. 2013;46(2):154-5.

45. Zahn A, Jennings N, Ouwehand WH, Allain J-P. Hepatitis C virus interacts with human platelet glycoprotein VI. J Gen Virol. 2006;87(8):2243-51.

46. Silva GF, Grotto RM, Verdichio-Moraes CF, Corvino SM, Ferrasi AC, Silveira LV, et al. Human platelet antigen genotype is associated with progression of fibrosis in chronic hepatitis C. J Med Virol. 2012;84(1):56-60.

47. Zhou SH, Liang XH, Shao LN, Yu WJ, Zhao C, Liu M. Association of human platelet antigens polymorphisms with susceptibility to hepatitis $C$ virus infection in Chinese population. International journal of immunogenetics. 2017;44(6):337-42.

48. Verdichio-Moraes CF, Toralles-Pereira C, Grotto RM, Silva GF, Pardini MI. Allelic frequencies of HPA-1 to 5 human platelet antigens in patients infected with hepatitis C virus. J Med Virol. 2009;81(4):757-9.

49. Blair P, Flaumenhaft R. Platelet a-granules: basic biology and clinical correlates. Blood Rev. 2009;23(4):177-89.

50. Yeaman MR. Platelets: at the nexus of antimicrobial defence. Nat Rev Microbiol. 2014;12(6):426-37.

51. Witte A, Chatterjee M, Lang F, Gawaz M. Platelets as a novel source of proinflammatory chemokine CXCL14. Cellular physiology and biochemistry : international journal of experimental cellular physiology, biochemistry, and pharmacology. 2017:41(4):1684-96.

52. Henn V, Slupsky JR, Gräfe M, Anagnostopoulos I, Förster R, Müller-Berghaus $\mathrm{G}$, et al. CD40 ligand on activated platelets triggers an inflammatory reaction of endothelial cells. Nature. 1998;391(6667):591-4

53. Chatterjee $M$, von Ungern-Sternberg SN, Seizer P, Schlegel F, Buttcher M, Sindhu NA, et al. Platelet-derived CXCL12 regulates monocyte function, survival, differentiation into macrophages and foam cells through differential involvement of CXCR4-CXCR7. Cell Death Dis. 2015;6:e1989.

54. Yount NY, Waring AJ, Gank KD, Welch WH, Kupferwasser D, Yeaman MR. Structural correlates of antimicrobial efficacy in IL-8 and related human kinocidins. Biochimica et Biophysica Acta (BBA)-Biomembranes. 2007; 1768(3):598-608.

55. Tsegaye TS, Gnirß K, Rahe-Meyer N, Kiene M, Krämer-Kühl A, Behrens G, et al. Platelet activation suppresses HIV-1 infection of T cells. Retrovirology. 2013;10(1):48. 
56. Auerbach DJ, Lin Y, Miao H, Cimbro R, DiFiore MJ, Gianolini ME, et al. Identification of the platelet-derived chemokine CXCL4/PF-4 as a broadspectrum HIV-1 inhibitor. Proc Natl Acad Sci. 2012;109(24):9569-74.

57. Parker ZF, Rux AH, Riblett AM, Lee FH, Rauova L, Cines DB, et al. Platelet factor 4 inhibits and enhances HIV-1 infection in a concentrationdependent manner by modulating viral attachment. AIDS Res Hum Retrovir. 2016;32(7):705-17.

58. Tang Y-Q, Yeaman MR, Selsted ME. Antimicrobial peptides from human platelets. Infect Immun. 2002;70(12):6524-33.

59. Torre D, Pugliese A. Platelets and HIV-1 infection: old and new aspects. Curr HIV Res. 2008;6(5):411-8.

60. Mohan KV, Rao SS, Atreya CD. Antiviral activity of selected antimicrobial peptides against vaccinia virus. Antivir Res. 2010;86(3):306-11.

61. Buck CB, Day PM, Thompson CD, Lubkowski J, Lu W, Lowy DR, et al. Human adefensins block papillomavirus infection. Proc Natl Acad Sci. 2006;103(5):1516-21.

62. Begonja AJ, Gambaryan S, Geiger J, Aktas B, Pozgajova M, Nieswandt B, et al. Platelet NAD (P) H-oxidase-generated ROS production regulates allb 33 -integrin activation independent of the NO/cGMP pathway. Blood. 2005:106(8):2757-60

63. Wachowicz B, Olas B, Zbikowska HM, Buczynski A. Generation of reactive oxygen species in blood platelets. Platelets. 2002;13(3):175-82.

64. Zander DM, Klinger M. The blood platelets contribution to innate host defense-what they have learned from their big brothers. Biotechnol J. 2009; 4(6):914-26.

65. Tilton C, Clippinger AJ, Maguire T, Alwine JC. Human cytomegalovirus induces multiple means to combat reactive oxygen species. J Virol. 2011; 85(23):12585-93.

66. Youssefian T, Drouin A, Massé J-M, Guichard J, Cramer EM. Host defense role of platelets: engulfment of HIV and Staphylococcus aureus occurs in a specific subcellular compartment and is enhanced by platelet activation. Blood. 2002;99(11):4021-9.

67. Jansen AG, Low HZ, van den Brand J, van Riel D, Osterhaus A, van der Vries E. Platelets can phagocytose Influenza virus which may contribute to the occurrence of thrombocytopenia during Influenza infection. Am Soc Hematology. 2016;128(22):1358.

68. Kullaya VI, de Mast $\mathrm{Q}$, van der Ven A, El Moussaoui H, Kibiki G, Simonetti E, et al. Platelets modulate innate immune response against human respiratory syncytial virus in vitro. Viral Immunol. 2017;30(8):576-81.

69. Hartwell DW, Mayadas TN, Berger G, Frenette PS, Rayburn H, Hynes RO, et al. Role of P-selectin cytoplasmic domain in granular targeting in vivo and in early inflammatory responses. J Cell Biol. 1998;143(4):1129-41.

70. Hottz ED, Medeiros-de-Moraes IM, Vieira-de-Abreu A, De Assis EF, Vals-deSouza R, Castro-Faria-Neto HC, et al. Platelet activation and apoptosis modulate monocyte inflammatory responses in dengue. J Immunol. 2014; 193(4):1864-72.

71. Chapman LM, Aggrey AA, Field DJ, Srivastava K, Ture S, Yui K, et al. Platelets present antigen in the context of MHC class I. J Immunol. 2012;189(2):916-23.

72. lannacone M, Sitia G, Isogawa M, Whitmire JK, Marchese P, Chisari FV, et al. Platelets prevent IFN-a/ $\beta$-induced lethal hemorrhage promoting CTLdependent clearance of lymphocytic choriomeningitis virus. Proc Natl Acad Sci. 2008;105(2):629-34.

73. Triantafilou K, Triantafilou M, Takada Y, Fernandez N. Human parechovirus 1 utilizes integrins av $\beta 3$ and av $\beta 1$ as receptors. J Virol. 2000;74(13):5856-62.

74. Nelsen-Salz B, Eggers HJ, Zimmermann H. Integrin avß3 (vitronectin receptor) is a candidate receptor for the virulent echovirus 9 strain Barty. J Gen Virol. 1999;80(9):2311-3.

75. Fleming FE, Graham KL, Takada Y, Coulson BS. Determinants of the specificity of rotavirus interactions with the $a 2 \beta 1$ integrin. J Biol Chem. 2011;286(8):6165-74

76. Mackow E, Gavrilovskaya I. Cellular receptors and hantavirus pathogenesis. Hantaviruses: Springer; 2001. p. 91-115.

77. Alvarez CP, Lasala F, Carrillo J, Muñiz O, Corbí AL, Delgado R. C-type lectins DC-SIGN and L-SIGN mediate cellular entry by Ebola virus in cis and in trans. J Virol. 2002;76(13):6841-4.

78. Shimojima M, Ströher U, Ebihara H, Feldmann H, Kawaoka Y. Identification of cell surface molecules involved in dystroglycan-independent Lassa virus cell entry. J Virol. 2012;86(4):2067-78.

79. Ahmad A, Menezes J. Binding of the Epstein-Barr virus to human platelets causes the release of transforming growth factor-beta. J Immunol. 1997; 159(8):3984-8.

\section{Ready to submit your research? Choose BMC and benefit from:}

- fast, convenient online submission

- thorough peer review by experienced researchers in your field

- rapid publication on acceptance

- support for research data, including large and complex data types

- gold Open Access which fosters wider collaboration and increased citations

- maximum visibility for your research: over $100 \mathrm{M}$ website views per year

At BMC, research is always in progress.

Learn more biomedcentral.com/submissions 